九州大学学術情報リポジトリ

Kyushu University Institutional Repository

\title{
SWALLOWING FUNCTION AND NUTRITIONAL STATUS IN JAPANESE ELDERLY PEOPLE RECEIVING HOME-CARE SERVICES : A 1-YEAR LONGITUDINAL STUDY
}

岡部，優花

ht tp://hdl. handle. net/2324/1654765

出版情報 : 九州大学，2015，博士（歯学），課程博士 バージョン：

権利関係：やむを得ない事由により本文ファイル非公開（2） 
(様式 3 ）

氏 名：岡部 優花

論文名 : SWALLOWING FUNCTION AND NUTRITIONAL STATUS IN JAPANESE ELDERLY PEOPLE RECEIVING HOME-CARE SERVICES: A 1-YEAR LONGITUDINAL STUDY

（日本の在宅療養要介護高齢者における䐵下機能と栄養状態に関する

1 年間の縦断研究)

区 分 : 甲

\section{論 文 内 容 の 要 旨}

要介護高齢者で低栄養状態になると、筋や骨の減少による運動機能低下や免疫機能の低下による感 染症の発症など様々な問題が生じる。要介護高齢者が低栄養状態に至る要因として摂食嚥下機能の低下 があるが、在宅要介護高齢者を対象にこれらの関係を調査した縦断研究はほとんどみられない。そこで 本研究では、在宅要介護高齢者を対象とし、睘下機能を含めた口腔状態が栄養状態に及ぼす影響を 1 年 間追跡して前向きコホート研究を行った。

研究対象者は福岡県在住の 60 歳以上の在宅療養要介護高齢者 339 名とした。ベースライン時に栄養 状態、口腔の健康状態（現在歯数と義歯の使用の有無）、嚥下機能、食形態日常の食事における刻み等 の加工の有無）、認知機能、全身状態、日常生活動作を評価した。1 年後に追跡ができなかった 76 名を 除く 263 名に対し、栄養状態の変化と死亡の有無を評価した。そのうちデータ欠損のあった 36 名と死 亡者 7 名を除外し、ベースライン調査において低栄養を認めない 177 名を分析対象者とした。統計解析 は、低栄養の発生を従属変数としてロジスティック回帰分析（変数減少法）を行った。

1 年後の追跡調査において低栄養を認めなかったものは 161 名 (91.0\%) 低栄養を認めたものは 16 名 （9.0\%）であった。低栄養を認めなかった群のうち 38 名（23.6\%）、低栄養群のうち 9 名 $(56.2 \%)$ の者 はそれぞれベースライン時点で燕下機能の低下を認めた。ロジスティック回帰分析の結果、嚥下機能低 下[（Risk ratio（RR:5.21)，95\% Confidence Interval (CI:1.65-16.43)] は低栄養との関連が認めら れた。一方、口腔の健康状態は低栄養との関連は認められなかった。

本研究の結果より、在宅要介護高齢者の低栄養状態の発生に燕下機能が関連していることが示唆され た。在宅要介護高齢者において、興下機能を考慮して口腔機能を維持、向上させることは低栄養の予防 や改善につながると考えられる。 